\title{
Seeing near and far: Balancing stakeholder needs and rights in Kazakhstan's educational reform
}

\author{
Jazira Asanova (OISE, University of Toronto)
}

\begin{abstract}
:
This paper examines the schooling reform in the post-socialist transformation of Kazakhstan. Adopting a rights-based approach to education, it looks at the ways in which the current education system addresses (or fails to address) the rights and needs of various stakeholders in the society, including teachers, learners, parents, civil society, and policymakers. Two recent large-scale educational reforms form the focus of the paper: a national standardized assessment and a transition from 11 to 12 years of schooling. Implications of the current reform initiatives for Kazakhstan's development are also discussed, pointing to lessons for understanding schooling and social change in post-socialist transformation.

Résumé

Cet article examine la réforme scolaire pendant la période de transformation postsocialiste du Kazakhstan. En adoptant une approche basée sur les droits de l'éducation, l'auteur considère les méthodes que l'actuel système d'éducation emploie pour répondre (ou ne pas répondre) aux droits et aux besoins des parties prenantes de la société, y compris, les enseignants, les apprenants, les parents, la société civile, et les responsables de politique. Cet article met au point le deux récentes réformes scolaires à grande envergure: la standardisation de l'évaluation nationale et l'ajout d'une année en plus à l'ancien système scolaire de 11 années. L'auteur y examine aussi les répercussions des initiatives de la réforme actuelle pour le développement du Kazakhstan, et suggère les leçons qui pourront nous faire comprendre l'éducation et le changement de la société dans la transformation post-socialiste.
\end{abstract}

\section{Introduction}

Kazakhstan, which is the size of Western Europe, is a Central Asian republic that straddles Europe and Asia both geographically and culturally. The strategic importance of Kazakhstan as an oil exporter is being increasingly recognized, given that its oil and gas reserves are regarded as the largest in the Caspian Sea basin. Western countries' interest in Kazakhstan's abundant oil is matched by their interest in promoting democratic values in this former Soviet republic, whose political reforms have been referred to as the "darker side" of Kazakhstan's success story. Yet, the trajectory Kazakhstan is following in its political, social and cultural arenas and its implications for the country's and the region's development remain insufficiently understood. As a multi-ethnic country, home to 
over 100 ethnic groups, and a secular society with an Islamic heritage, Kazakhstan provides an interesting case for making sense of schooling and social change, including the processes of nation building and social cohesion.

As Central Asian countries emerged independent after the collapse of the Soviet Union in 1991, their education systems were expected to fulfill some key objectives in these societies' post-socialist transformation. In the postindependence decade, countries of Central Asia faced the daunting task of revising the curriculum, organization, and governance of schools (DeYoung \& Suzhikova, 1997). More dramatically, they embarked upon the process of de-constructing and re-constructing national identity in their multi-ethnic societies, increasingly viewing education systems as a vehicle to exhibit their national distinctiveness and differentiation in the process of nation building (Chapman et al, 2005).

Research on educational reform in Central Asia has largely centered on the politics of adoption of certain reforms, as scholars of comparative education increasingly acknowledge the growing influences of global forces on national education policies (Carnoy and Rhoten, 2002; Mundy, 1998, 2007; Dale and Robertson, 2002). However, equally important is a need to deepen our understanding of the regional, national and even local social, economic, and political conditions that mediate the implementation of responses to global pressures for reform. It is essential to understand how challenges to current institutional forms of schooling and preferred solutions are constructed nationally and to examine their implications for the structure, culture, and organization of education at national, subnational, and regional levels.

This paper focuses on the educational reform in Kazakhstan, and offers a wide-angle lens for examining key educational issues and challenges, by discussing areas in which progress, stagnation and even regression, have taken place. Adopting a rights-based approach to education, it looks at how educational policies and practices are linked to local histories and to international mechanisms in construction of educational aims and the ways of achieving them. It is essential to analyze and challenge the ways in which the current education system addresses (or fails to address) the rights and needs of various stakeholders in the society, including teachers, learners, parents, civil society, and policymakers. Finally, the paper attempts to locate 'congruent educational practices appropriate to coping with the tasks laid upon schools by a society' (Anderson, 1961, cited in Edwards, 1973) in the Central Asian context.

I begin the discussion by providing a broad overview of Kazakhstan's education system in a historical perspective and then discuss current imbalances in planning and implementation of educational reforms, including two large-scale initiatives: a transition from 11 to 12 years of schooling and a nation-wide standardized assessment (the Unified National Testing - UNT). Finally, I discuss the implications of these reforms for the educational development of Kazakhstan.

\section{Theoretical considerations and research methods}

A scholarly debate on Central Asia, including Kazakhstan has focused on the ways in which education in these post-Soviet states is shaped by the interplay 
between the local dynamics, the past traditions, and the broader context of globalization. For instance, Chapman et al (2005) stated that Central Asian republics' quest for quality education in the post-independence decade was accompanied by aspirations to align their education systems with the 'world model' on one hand, and on the other hand, by a desire to recapture the Soviet levels of achievement in education, including universal literacy, free education at all levels, accessibility of higher education, and the academically vigorous orientation of education. As Central Asia entered the new millennium, the education reform rhetoric in this region became increasingly embedded in the global discourses, which travel in part through the work of international organizations, philanthropic foundations, bilateral agencies and social movements. Global discourses become particularly important in newly independent nationstates for purposes of legitimation, international recognition, nation building and mobilization (McNeely, 1995).

At the same time, observers have raised concerns about whether countries in the post-Soviet transformation adopt international discourses without being truly committed to the values embedded in these discourses (Janmaat and Vickers, 2007). Silova (2005), for instance, argued that in the post-Soviet context, local education stakeholders may 'appropriate the language of the new allies', while not necessarily agreeing with it or being willing to implement it. Thus, national education stakeholders may effectively internalize international discourses, while using them for their own needs such as legitimizing contested educational reforms domestically, objectifying value-based decisions, or 'signaling' certain reform movements internationally. In the case of Kazakhstan, a move to a two-tier higher education that includes a bachelor and master's degrees reflects its aspirations to align with European education systems.

Like other post-Soviet countries, Central Asian republics emerged out of the Soviet system, whose ideological concerns have fostered narrow constructions of education and its goals. Education was considered key in transforming the underdeveloped agricultural economy of the Soviet Union into a modern, industrial, technological giant, and schooling became a chief channel for acculturation to the Soviet way of life and developing a Soviet person, dedicated to the ideals of communism. The structure, content, and governance of Soviet schools were thus subordinated to this overriding goal. In the process of postsocialist transformation, post-Soviet countries embraced - at least formally - the principles of liberalism, democracy, and the rule of law (Janmaat and Vickers, 2007). In addition, the shifting territorial identities in these countries brought to the foreground the importance of nation building.

Given the multiple and complex societal objectives, official discourses in Central Asian republics became increasingly marked by constellations of contradictory ideologies that nevertheless formed a coherent set of ideas, to borrow from Lisovskaya and Karpov ${ }^{1}$ (1999). For instance, Kazakhstan's national identity reflects a set of hybrid constructions that embrace modernization, international integration, and poly-culturalism (Blum, 2003), in addition to patriotism and nationalism, with implications for the schooling and its aims. 
At the same time, the concern with education quality in Central Asia became rather narrowly focused on raising student learning (Chapman et al, 2005). This is consistent with Stromquist's (2006) assertion that the discussion of quality is often framed to center on performance in standardized tests, sidestepping the issues of citizenship, rights and duties, inequity and conflict in society. In recent years, a scholarly discussion around the quality of education has centered on the multiple functions of schooling that go beyond the transmission of cognitive knowledge, with a focus on human rights, multicultural learning and recognition of social difference, global citizenship, active citizenship and social justice. International conventions and development targets, including the Education for All (EFA) commitments emphasized the redistributive role of education and the role of the state in ensuring equity of access to quality education, particularly among disadvantaged groups, as the gaps between rich and poor continue to widen in various national contexts. Further, given shifting territorial identities and multiethnic composition in many countries, scholars have turned their attention to notions of citizenship and in particular, to education's contribution to the development of active citizens capable of thinking critically about structural causes of social issues, political developments and political demands, as well as to make independent decisions regarding the social and political future of the society they live in (Fagerlind and Kanaev, 2000; Kahne and Westheimer, 2003; Saha, 2000; Tse, 2003). Active citizenship contrasts compliant forms of citizenship in totalitarian regimes, where citizens are expected to participate but not question the existing structure, and entails more than voting, but participating fully in the decision-making processes with a view of social change and social justice. Increasingly, too, the idea of inclusive schooling, which calls for education that responds to the concerns, aspirations, and interests of diverse students and enables every student to identify and connect with her/his social environment, culture, population, and history (Dei, 2005) has taken hold.

To what extent has Kazakhstan's educational reform reflected recent debates on the quality of education? This paper attempts to address this question by drawing on state policies related to education and nation building; reports on the education sector produced by the national educators and international organizations; media coverage of educational reforms in national newspapers in Kazakh and Russian languages; academic and professional publications produced by Kazakhstan's educational institutions; the official curriculum, and a pilot survey and interviews with Kazakhstan's educators, including teachers and school administrators. The survey ${ }^{2}$ and the interviews ${ }^{3}$ were conducted to gauge local conceptions about educational reforms currently underway. All translations of the quotations from Kazakh and Russian into English are the author's.

\section{Context: Kazakhstan and its educational development}

Kazakhstan is the largest country in Central Asia, occupying two million square kilometers and bordering with China, Kyrgyzstan, Russia, Turkmenistan, and Uzbekistan. Historically, the region that encompasses modern Kazakhstan was part of the Silk Road - global trade routes that were disrupted in the early $14^{\text {th }}$ 
century with the disintegration of the Mongol empire and the shift of global trade to maritime routes in the Indian Ocean and across the Atlantic (Johnson, 2004). Russian domination of Kazakh steppes in the $18^{\text {th }}$ and $19^{\text {th }}$ centuries gave way to Sovietization, as Bolsheviks seized control in 1917.

Kazakhstan's major languages spoken are Kazakh and Russian, and major religions are Islam and Christianity. Its population of over 15 million is multi-ethnic (over 100 ethnicities). During the Soviet period, Kazakhstan was reportedly the only Soviet republic with the indigenous ethnic group (Kazakhs) in the minority. However, their proportion has steadily increased since the country's independence in 1991, accounting for 57\% of the population in 2004 (NHDR, 2004). In the same period the proportion of Russians decreased (27\% in 2004) and simultaneously Russians have gradually suffered a demotion of status (Dave, 2003, cited in Kissane, 2005). Other ethnic groups, including Ukrainians, Uzbeks, Germans, Koreans, and Uigurs represent $15.6 \%$ of the population or 2.3 million people. Most of these nationalities were resettled to Kazakhstan during the Soviet rule.

At the turn of the $20^{\text {th }}$ century, Kazakhstan was largely a nomadic culture, with most Kazakhs remaining illiterate, "concerned with the affairs of pastoral life or the struggle to survive on the fringes of settled life" (Bacon, 1980, p.101). Education in pre-Soviet Kazakhstan remained largely Islamic. Towards the end of the $19^{\text {th }}$ century, Russian colonial policy makers made efforts to provide targeted educational opportunities for Kazakhs, in the form of aul schools for nomadic children and Russian-Kazakh schools for the children of local elites. In the 70 years leading up to the October Revolution in 1917, only 1000 Kazakh youth received secondary and higher education (Abzhanov, 2005), primarily in tsarist Russia. By the time the Soviet Union dissolved in 1991, Kazakhstan's population reportedly achieved universal literacy.

Kazakhstan inherited a comprehensive educational system from the Soviet period: kindergartens, boarding schools, vocational schools, special education schools and schools for gifted children, in addition to primary and secondary schools. Following Kazakhstan's independence, this educational network started to deteriorate as public expenditures on education rapidly declined. During the 1990s, education was a second-order priority and was targeted as an area to cut costs in favor of a private sector development (DeYoung and Suzhikova, 1997). Public expenditure on education as a proportion of gross domestic product (GDP) declined by more than half - from 6.8\% in 1990 to $2.9 \%$ of a much smaller GDP in 1994 (ADB, 2002), not exceeding 3.6\% after 2000 (NHDR, 2004).

In the early to mid-1990s, the debate over the direction and organization of public schooling in Kazakhstan was marked by a circulation of innovative ideas on teaching and learning in the post-Soviet space (DeYoung and Suzhikova, 1997) on one hand, and by a lack of consensus and a unified course at the level of the Ministry of Education on the other. Issues for which there was little consensus included "the allocation of roles and responsibilities, languages of instruction, educational standards, communication flows, reporting relationships, distribution 
of authority across levels of the education sector, and most crucially, degree of centralization between national and local bodies" (Chapman et al, 2005, p.516). A weakened capacity for educational policy formulation in the republics, given that educational policy formerly originated from Moscow, was compounded by recurrent turnovers in the leadership of the Ministry, resulting in frequent staff attrition and reorganizations. It was common for the ministerial portfolio to change hands every one to two years, and simultaneously, for the Ministry of Education to be amalgamated with various line ministries for cost-saving purposes. For instance, in 1998, the Ministry of Education was a part of a large octopus, consisting of eleven previously autonomous ministries and state departments, including ministries of health and culture. The Ministry's division on Secondary Education alone saw dramatic cuts in staff from 220 in the early 1990s to 26 several years later.

Thanks to the substantial fossil fuel reserves, abundant supplies of other minerals and metals, and a large agricultural sector featuring grain (and increasing prices for these commodities in world markets), in addition to economic reform and foreign investment, Kazakhstan experienced solid economic growth after 2000, making it the wealthiest of the Central Asian republics, with a per capita GDP of $\$ 1,780$ (USAID, 2004). The year 2001 marked a long-awaited break for funding in the education sector: the first time in many years it increased significantly by 19.3 billion tenge (about US\$ 1.2 million). After 2003, the share of education in total national expenditures increased from $11.9 \%$ in 2001 to $14.1 \%$ in 2003 (the average share of education in OECD countries in 1999 was 12.7\%) (NHDR, 2004). Funds were earmarked for the development of preschool education, a domain that suffered most severely from the lack of resources in the 1990s, rural schools, and higher education.

\section{Aims of education and the means for achieving them}

Robust economic growth was accompanied by a renewed emphasis on education as a means to economic development and increasing the country's competitiveness in the global world. As the government declared that "competitiveness of a nation is primarily characterized by the level of its education” (NHDR, 2004), educational policies became increasingly defined in a way that reflected the central government's objectives for economic development, with a growing focus on the correspondence between economy and education. The signing of the Lisbon and Bologna agreements signified for Kazakhstan the process of "integration into the world education community as an equal member" (NHDR, 2004, p.19). The discourse on school reform in Kazakhstan became increasingly steeped in the language on 'world education standards'.

The global discourses on human capital and the knowledge economy culminated in two highly visible reforms in education: the extension of the duration of compulsory primary and secondary education from 11 to 12 years, and the institutionalization of a standardized national assessment - the Unified National Testing. Both reform initiatives embed notions of competitiveness, exam-oriented success, and knowledge acquisition. They were complemented by 
the adoption of the outcome-based education framework at the Ministry of Education.

The extension of the duration of compulsory primary and secondary education from 11 to 12 years, planned to take place in 2008, is part of Kazakhstan's plans to 'modernize' the school system. The move was intended to increase the country's competitiveness in the global world, by fostering "a higher level of the population's education levels" (Mukanova, 2005), and ensuring recognition of Kazakhstan's secondary education certificates by universities internationally (Minister of Education, 2005). The proposed reform envisions changes beyond a simple addition of one year of instruction; it aims at redistributing the number of years students spend in the primary, middle secondary and upper secondary school and is also regarded as an opportunity to make systematic revisions of the school content, given Soviet holdover tendencies, including curriculum overloading, dogmatism, and factual orientation.

The Unified National Testing reflects a concern about raising student learning by assessing school graduates' mastery of the school program on one hand, and tackling academic corruption in university admissions, on the other. First implemented in 2004, the UNT integrates the final attestation of secondary school graduates and entrance exams to higher education institutions. As a final graduation exam, UNT is a step forward compared to the old system of schooladministered assessment that relied on teacher judgment (Zajda, 2003). It consists of four exams: the three mandatory exams include language (Kazakh or Russian, depending on the language of instruction), history of Kazakhstan, and mathematics and the fourth exam is an elective, based on a prospective university major. Performance on UNT is used to allocate state scholarships and to predict college success.

Simultaneously, education's contribution to Kazakhstan's nationbuilding project became broadly acknowledged. The government has declared a multi-cultural policy and a need to maintain ethno-cultural consensus as an important condition of progress and Kazakhstan's prosperity (Kontseptsia, 2005). At the same time, fostering a national feeling has involved the search for unifying themes such as patriotism, civic duty, common ancestry and destiny, with a goal of stimulating national consciousness and instilling in youth a sense of pride and civic allegiance. In the area of education, patriotic education and language policies became salient issues.

In summary, Kazakhstan's education system was expected to fulfill the multiple and competing goals of international integration, multiculturalism, modernization, patriotism and ethno-nationalism. How such goals have translated for a wide base of stakeholders in the education system is the focus of the discussion below.

\section{Imbalances in education}

The new millennium was accompanied by deepening inequalities at all levels of education, given the rising costs of education and the increasing gulf between social groups in Kazakhstan. New forms of inequality have emerged through the 
proliferation of private schools and universities for the elite with lower quality and prestige for the disadvantaged. The growing stratification of the society has predictably affected the most the low-income groups, youth and adults from rural and remote areas, and children with special needs.

Systemic imbalances in educational quality and provision between rural and urban schools can be seen on almost every educational indicator, and the most salient issues include declining achievement and completion rates, the deteriorating school infrastructure, a shortage of qualified teachers, and differentiated access to quality education. For example, of about 3 million students enrolled in 8254 schools in 2003-2004, 11\% attended 1968 innovative schools, including lyceums, gymnasiums, and schools with in-depth study of certain subjects (math and sciences, foreign languages, and humanitarian disciplines). At the same time, the share of rural students enrolled in these innovative schools was only 4.6\% (NHDR, 2004).

Inequalities in rural-urban education were exacerbated by a massive closure of small-sized schools ${ }^{4}$ located primarily in rural areas, following the 'rationalization' ${ }^{5}$ policy supported by the Asian Development Bank in the late 1990s. Small-sized rural schools were integrated with neighboring schools 'to reduce administrative, maintenance, and instructional costs' (Asanova, 2006). The 'rationalization' policy also affected Kazakhstan's preschools, more than $80 \%$ of which have closed since the collapse of the Soviet Union. In 2004, about $20 \%$ of children under 7 nationwide and only $2.4 \%$ in rural areas were enrolled in preschools, giving children in rural areas low starting opportunities in education ${ }^{6}$. Kazakhstan's vast territory, low population density, and uneven economic development compounds the issue of rural-urban schooling inequalities. According to a UNICEF study, more than 30,000 children in 2001 had to walk to school a distance of 5 to $40 \mathrm{~km}$.

Completion rates at the basic education level (grade 9) have been falling gradually, from $84 \%$ in 2000 to $81 \%$ in 2002 . In some cases rural schools can only provide primary or incomplete secondary education, which is one of the reasons an increasing number of rural children do not complete their secondary education. Attendance rates have been even lower, particularly among students from disadvantaged families (NHDR, 2004). The main reasons for non-attendance, according to the 2004 survey conducted by the non-governmental Education for All association, included the need to work within or outside of the household, inadequate motivation, hostile peers (humiliation of poor pupils), problems in relation to teachers, and in-school violence.

UNESCO research and the nationwide standardized assessment suggest that student achievement rates have been gradually declining (Zharkynbaeva, 2005). In the first year of the UNT, almost one quarter of test takers failed the exam (scoring less than 40 out of 120 ) and only $0.7 \%$ of test takers scored high (101-120). Further, $70 \%$ of contenders for the highest distinction certificate did not score high enough to receive it, supporting a widespread perception about grade inflation in Kazakhstan's schools (Duysebek, 2004). Disparities in performance across the country also became evident: on average, students in 
Russian-medium schools scored higher (54.7) than students in Kazakh-medium schools (50.6). Urban school graduates had a higher average score (55.5) than graduates of rural schools (48.1). There were regional differences as well, with one region (Mangystau) garnering the highest proportion of students with the lowest scores (35.7\%). Significantly, Mangystau is a region with the highest proportion of poor rural population, which partly might explain this achievement gap.

It is estimated that 45,000 children with various disabilities ${ }^{7}$ do not receive adequate education, given the lack of trained staff and more importantly, well-defined policies with respect to most vulnerable children. Attempts to mainstream disabled children into standard schools have not worked out well; in rural areas, parents keep children with special needs out of school to safeguard them from social stigmatization.

According to the Ministry of Education and Science, $42 \%$ of Kazakhstan's schools were operating in substandard buildings and 22\% of schools required major repairs in 2002. Thus, only 32\% of school buildings nationwide met the state standards. Further, almost $15 \%$ of schools lacked minimal sanitation, heating and lighting, and almost half (44\%) did not have a primary healthcare staff member. Nearly one third of schools have no gymnasium or cafeteria, and a similar proportion lacks equipment for science classes. Two thirds of schools operated in several shifts and in some regions (Mangistau and South Kazakhstan), schools operate in three or four shifts.

The growing social gulf has had negative effects on the educational ambitions of low-income parents for their children (NHDR, 2004). According to the Household surveys by the Statistics Agency of the Republic of Kazakhstan in 2002, $60 \%$ of children from poor families have no opportunity to continue their education to higher education. While there has been a slow formation of the middle class, almost one third (30\%) of Kazakhstan's population lives under the poverty line, according to official government statistics. As could be expected, the majority of people (82\%) with only primary education were unemployed in 2003, compared to $28 \%$ of those with secondary education and $15 \%$ of people with higher education. While private schools mushroomed in the post-independence decade, their growth has reached a plateau, suggesting that the system of private schools and its contingent (some 20,000 students) is well formed, serving children from higher socio-economic backgrounds.

\section{Quality or equity?}

In Kazakhstan, education became overwhelmingly regarded as a tool for economic competitiveness rather than for achieving life purposes (NHDR, 2004). The concern with education quality was rather narrowly focused on raising student learning (Chapman et al, 2005), with inadequate attention to issues of equity. Stromquist (2006) asserted that issues of inequality are often not perceived of as in need of correction, except when inequality threatens political stability. The efforts to serve the disadvantaged groups, comprising mostly rural areas and minority groups, are scarce and typically reach a small segment of those in need. 
More broadly, Kazakhstan's educational policy framework grounded in an economic paradigm appears to be consistent with the neo-liberal policies institutionalized at the World Bank, revealing the underlying tensions between the World Bank's market-oriented philosophy and equity-based poverty reduction goals (Culpeper, 1997; Jones, 1997; Lauglo, 1996).

Yet, equity and quality in education should be addressed simultaneously (Samoff, 1996) and the state must intervene not only to promote economic growth, but to ensure distributive justice. While pressure to expand access to quality education is in large measure generated by international agencies (in the context of the Millennium Development Goals and the Education for All priorities), which fund education reform initiatives, their significance as resource providers in Kazakhstan appears to have decreased after 2000. Between 1995 and 1998, the Asian Development Bank extended two educational loans to the government of Kazakhstan totaling \$65 million, in addition to technical assistance grants. In the late 1990s ADB staff reported plans for extending a third education loan worth $\$ 40$ million; however, it was not signed eventually. Notably, the ADB's 'rationalization' policy, discussed above, was considered a fiasco, adding to education policy makers' weariness about external influences. While UNESCO works with the Ministry of Education on integration of the Education for All priorities and strategies within the national development plan in education, funding priorities have not yet reflected these strategies.

What raises concerns is that both large-scale reforms under discussion are likely to exacerbate existing inequalities, rather than address differences in education quality between rural and urban schools, and Kazakh-medium and Russian-medium schools, inherited from the Soviet period. Given Kazakhstan's multi-ethnic mix, it also remains unclear how the country's small sized ethnic minorities will fare under the new model of education, and for example, whether provisions will be made for ethnic minorities to take the UNT in their native language.

\section{Planning and implementation of reforms}

Kazakhstan's educators acknowledge that educational administration and governance is the system's weakest link (Duysebek, 2005), remaining conservative and authoritarian, rather than consensus-driven and reflexive. While educational reform remains a highly contested issue, given that different groups have varying conceptions of what is problematic, educational policy continues to be centrally planned and directed. For example, the UNT, which Drummond (2006) called a new selection regime, was implemented swiftly following a Presidential decree, and its development has involved neither research nor pretesting. In contrast, Russia, where a similar initiative is being implemented has favored an incremental approach to nationwide student testing.

In the 1990s Kazakhstan moved toward educational decentralization, which increasingly came to be regarded as a reduction in the government support, rather than a means of increasing local relevance and providing mechanisms and venues for teachers and other stakeholders to express their views. The top-down 
approach to education policy making in large measure excludes teachers and other stakeholders from decision-making, and teachers are regarded as technical implementers of centrally defined reforms, not as key players in educational change.

A lack of attention to an increasingly inexperienced, poorly paid, unmotivated, and underqualified teacher force is likely to undermine reform success. As in other Central Asian countries, the teaching profession has suffered a demotion of status, resulting in a shortage of qualified teachers, especially in rural areas. Overall, only one half of the graduates from teacher training institutes went to work at schools in 2003, and fewer still went to work in rural schools (NHDR, 2004). In the same year, up to one-third of teachers entering the profession did not have teaching qualifications. Although funds from the government budget in the form of 5000 scholarship grants were earmarked for teacher training, with priority given to teachers of Kazakh and foreign languages, elementary school teachers, preschool and vocational education (Minister of Education, 2005), the incentives to teach, especially in rural areas, remain very low.

Interviews conducted for this study indicate low support for the 12-year education reform among teachers, who feel that added responsibilities and high expectations have not been balanced by support to teachers in the form of adequate instructional materials, in-service training, and remuneration. The current weak support for teacher capacity building needs to give way to deep and sustained attention to teacher training programmes. At present, teaching in Kazakhstan's higher education continues to emphasize "pedantic, procedural, task-related knowledge, and rote learning” (Rao and Rubina, 2005). Further, adequate programs in curriculum development and educational administrators are few and far between.

Importantly, a top-down approach to policy making has led to insufficient attention given to the core matters of educational processes, including learning environments and pedagogies. Given the high stakes nature of UNT, its 'wash-back' effects on teaching, learning and curriculum (including teaching to the test), especially at the upper secondary level, is significant (Drummond, 2006). Unlike in Kyrgyzstan and Georgia in the Caucasus, where the national assessment is based on an aptitude test, UNT is content-oriented, as it tests students' factual knowledge in four subjects ${ }^{8}$. Interviews, reports, and the survey results indicate that overall, UNT is regarded as a positive initiative that tackles corruption in higher education. However, teachers had mixed reactions to UNT as a graduation exam of secondary school leavers. They stated that UNT promotes rote learning and memorization, as it assesses the knowledge of facts, not understanding of concepts, and eschews students' interests towards school subjects that are tested by UNT. Fundamentally, UNT's fact-testing nature contradicts the adopted outcome-based education framework, which de-emphasizes subject-based competencies, memorization and rote learning, and highlights critical and reflexive thinking. 
Although literacy stands at $99.5 \%$ percent, preliminary research suggests that functional literacy, defined as students' ability for active participation in the social life, is low, as teaching remains oriented towards factual information. Findings of a pilot study using the PISA (Programme for International Student Assessment) methodology, conducted among students of general schools, lyceums and gymnasia in the Karanganda region, indicated that $66 \%$ of students from general schools (and 23\% of students from lyceums and gymnasia) were not capable of applying knowledge obtained in school in real life situations (NHDR, 2004). Students had particularly low functional literacy in the natural sciences (57\%) and literature (37\%). Authors of the report noted that these results might be explained by the insufficient practical orientation of education materials in the natural sciences and literature and the specific isolation of such materials from the real life surrounding the students; a congestion of the curriculum in these subjects by theoretical information; and insufficient attention to higher order thinking skills, such as problem solving and analysis.

It is a cause for concern that UNT is regarded as an 'objective' means for a comparative analysis and rating of schools based on the test results (Kovzhasarova and Salina, 2005). Education policy makers tend to view the reasons for the achievement gaps as residing with schools, rather than occurring due to structural inequalities, including inequalities in learning opportunities for privileged and disadvantaged students (Zajda, 2003). More broadly, variability in regional financing, deficiencies in teacher training, teacher qualifications, school administration, and provision of curricular materials and other forces beyond education contribute to the learning gaps UNT results seem to suggest. Valyayeva (2006) noted that UNT does not unequivocally address the issue of transparency, for it is administered by the Testing Centre, under the auspices of the Ministry of Education. In contrast, in neighboring Kyrgyzstan national assessment is led by an independent NGO. Further, teachers indicated that, under some conditions, test answers could be made available to students.

With respect to the 12-year schooling, it is yet unclear whether this reform will be accompanied by a substantial curriculum revision. Silova (2005) suggested that so far the interest among the policy makers has been in minor structural changes, rather than in a major overhaul of the school content. For example, the reform's exact formula for the three tiers (primary, lower and upper secondary levels) is the subject of a debate, primarily between education officials and education researchers. Two structures have been proposed: $4+6+2=12$ and $5+4+3=12$, with arguments for and against increasing the duration of the primary, middle, and upper secondary levels of schooling (Kusainov, 2005). Given the looming effective date of the reform (2008), such discussions suggest that the reform concept and its implementation may have lacked a full consideration and careful planning at the outset. To facilitate the implementation of the 12-year reform, MOES reported studying the experience of Russia and the Baltic republics of moving to 12 years of schooling, yet, full implementation is a daunting task. The transition of over 8000 schools to the new model will be based on the results of a small number of pilot schools (104 schools in 2005). However, the pilot 
schools were selected based on their material-technical base, and do not represent an average school in Kazakhstan. While a national research center was created specifically to address the transition to 12 years of schooling, it has been primarily concerned with developing probationary curricula and textbooks for Grades 1-5 in pilot schools.

It can be concluded that the system has a low capacity to transition to the 12-year schooling, given large regional and urban/rural disparities, shortage of qualified staff and inadequate incentive structures, decreasing school attendance and retention rates, especially by students in disadvantaged families, and growing gaps in access to quality education. Implementation is likely to run into difficulties in the country's small-sized schools, which make over $50 \%$ of the total number of schools. As the new model envisions teaching a foreign language and computers starting in Grade 2, a practice prevalent only in Kazakhstan's specialized schools, a lack of qualified teachers will hinder the teaching of computers, a foreign language and advanced courses in small-sized schools. Education officials hope that existing inequalities between urban and rural schools will be leveled using distance education, training of multi-grade teachers, and the use of education consultants to address the needs of individual schools.

Large-scale changes require building new roles and relationships among various education stakeholders, to enhance chances of the reform's success. The UN report on education (NHDR, 2004) noted that the Ministry of Education could benefit from involving a wider range of concerned stakeholders in forming and implementing educational policies, including parents and the civil society. If Kazakhstan broadens the base of stakeholders involved in policy-making, rendering the latter an open debate about the goals of education and how they should be achieved, its various constituencies might benefit more from the educational reforms.

\section{Language and the nation-building challenge}

One of the key challenges in Kazakhstan's nation building process is balancing the official multi-cultural policy and the state's ethno-nationalizing project, driven primarily by the cultural intelligentsia. The ethno-nationalizing project has arisen as a reaction to the Sovietization and Russification policies of the Soviet state, leading to a weakening of local culture and traditions of ethnic groups under the USSR and to the majority ethnic group's assertion of its culture and identity starting in the late 1980s. Given Kazakhstan's multi-ethnic mix and complexities in the Soviet nationalities policies, how Kazakhstan chooses to negotiate notions of home and belonging has implications for the social cohesion, stability, and development in this country (Heyneman, 2000; Kissane, 2005; DeYoung and Nadirbekyzy, 1996).

Given the role of the school curriculum in transmitting to youth selective versions of knowledge that represent official values, including a sense of national identity (Apple, 1995), education policy makers have regarded Kazakhstan's history and literature curriculum as particularly suitable for promoting national identity. Curriculum for these two subjects reflects the tensions in Kazakhstan's 
nation-building project discussed above: Kissane's (2005) research on Kazakhstan's history curriculum suggests that history textbooks maintain a “delicate balance” between ethno-nationalizing and multicultural identities. In the case of the literature curriculum for Kazakh-medium schools, the balance has tipped in favor of promoting national distinctiveness based on the cultural heritage of the majority ethnic group (Asanova, 2007), with insufficient attention to intercultural and multicultural learning and to different notions of citizenship. At the same time, textbooks in these subjects promote narratives that focus on national self-determination. As Janmaat and Vickers (2007) noted, by highlighting 'historical injustices' committed by 'foreign oppressors', such narratives carefully construct an argument legitimizing the newly attained political independence. It has been argued that the historiographies in countries of post-socialist transformation are as monolithic and totalizing as those of their communist predecessors. Asanova (2007) noted that to promote the state's articulated goals of social cohesion and inclusive national identity, the society's linguistic, cultural and ethnic diversity needs to find reflection in the school curriculum, through a multicultural dialogue.

The issue of language of instruction is another challenging area of postsocialist educational reform in Kazakhstan. According to Kazakhstan's Constitution, Kazakh is a state language, while Russian has a status of an official language, to be used in state organizations and self-government, and as a language of interethnic communication. On one hand, each citizen of Kazakhstan is expected to know Kazakh, Russian, and a foreign language, as outlined in a state normative document on educational goals and functions (Kontseptsia Obrazovania [the Concept of Education]). On the other hand, language policies in Central Asia, including Kazakhstan have focused on enhancing the status of the titular language, given the Russification process in the Soviet Union. The need to increase the teaching of Kazakh language in schools and universities continues to be emphasized, with plans to increase the number of hours Kazakh language is taught in universities to 270 hours and in Russian-medium schools to four hours a week in 2006/07.

A major theme of research in Kazakhstan is determining whether language policy is successfully increasing the status of the state language, Kazakh, relative to Russian, or whether Russian retains its predominance over Kazakh in high status spheres, including education (Bahry et al, forthcoming). Currently, Kazakh language learning in Russian schools and Russian language learning in Kazkah schools is weak. Bahry et al stated that in monolingual Kazakh-schools, the Russian proficiency students derive from Russian as a Second Language classes may be insufficient to have a working command of the literary language; at the same time, many Kazakhs opt for Russian-medium schooling, in which case, they develop weak Kazakh proficiency. According to Suleimenova and Smagulova (2005), about 15\% of ethnic Kazakhs speak only Russian, and another $25 \%$ have weak proficiency. For Russians, there is still a very low level of reported proficiency in Kazakh, despite surveys that suggest an increased 
willingness to learn Kazakh. Other Russified, non-Turkic minorities are likely not to acquire Kazakh proficiency if it means giving up their Russian proficiency.

Further, with regards to Kazakhstan's numerous, if small sized nationalities, Kazakhstan's laws indicate that conditions should be created for the realization of their cultural and language interests. While the laws make provisions for ethnic minorities to receive education in their native language, state funding is not always available. In reality, seven ethnic minorities have schools with instruction in their native language. In 1999-2000, 80,000 students (2.3\%) received instruction in Uzbek, 23,000 (0.6\%) in Uigur, and 2,300 (0.07) in Tajik (Gosudarstvennaia Programma, 2006). In addition, 14 heritage language classes are offered in areas of compact settlement and large populations of these ethnicities (Suleimenova and Smagulova, 2005). In general, Kazakhstan's smaller nationalities have traditionally enrolled in and continue attending Russianmedium, rather than Kazakh-medium schools. In 1999-2000, 1.5 million students (45\%) received instruction in Russian.

Given Kazakhstan's ethnic diversity, Bahry et al (forthcoming) stated that a strong form of bilingual/trilingual education might provide the young generations with proficiency in both the literary form of the native language, the state and the official language. In 2001, Bekturganov, a former Minister of Education, proposed a three-language education program that would have entailed teaching academic subjects concurrently in three languages: Kazakh, Russian, and English (e.g. Math in Russian, Geography in English, and History in Kazakh) among students of 12 years and older. However, other educators and officials leveled criticisms against this approach on the grounds of fiscal unfeasibility and competing priorities in education in a resource-scarce environment.

\section{Concluding remarks}

Despite the economic growth and notable progress that has taken place in the education sector, Kazakhstan is a country of vast lands where many schools are small-sized; located in rural areas; to which many students must walk long distances; and are served by under-qualified teachers (HDR review). As Kazakhstan's annual growth rate solidified at $10 \%$ and the share of education in total national expenditures increased ${ }^{9}$ after 2000, the increased education budgets were insufficient to achieve the goals of access, learning and completion. The systemic imbalances in educational quality and provision remain unresolved, and the fragmented, contradictory reforms in education, exacerbated by gaps in capacity and funding, run the risk of deepening the existing inequalities.

Providing access to education of adequate quality may require Kazakhstan's educators and policy makers to balance multiple tensions between active citizenship and the promotion of patriotic values; between monolithic and multiple identities in the process of nation building; between aspirations to integrate into the world economy and the continuity of past traditions that include, as well as predate and transcend, the legacies of the Soviet period. The imbalances 
discussed in this paper also hint at the tensions between priorities of the central government, various line ministries and the Ministry of Education.

It is hoped that building collaboration and balancing stakeholder needs in comprehensive education reform will be accompanied by (a) building capacity at local and national levels, including training of evaluators and test developers, educational administrators, curriculum developers, and teachers; (b) direct attention to improving educational processes and instruction; and (c) developing better linkages among the reforms. For instance, the potential of the UNT to assess the progress of the transition to the 12-year schooling and planned changes in the curriculum cannot be underestimated. At the same time, the character of the UNT needs to be revised to match the adopted framework of outcome-based education, which emphasizes a move towards teaching critical thinking and skills and attitudes required to function effectively in a changing society.

The need for an integrated approach in reforming the education system through building capacity and consensus among the various stakeholders may require consideration of education from a rights-based perspective, where learners, teachers, parents, the community, the civil society and policymakers participate in the creation and re-creation of meanings and values in education. Given that educational change is conflictual and political, achieving vision and a consensus will require finding the right discourse that brings all actors of the society onboard (Farrell, 2000).

\section{Notes:}

1. In the context of Russia's revision of the school curriculum in the 1990s, Lisovskaya and Karpov (1999) asserted that the textbook content has shifted from a cohesive presentation of the key principles of Marxism-Leninism to a constellation of contradictory ideologies including nationalism, Westernization, and reinterpretation of communism.

2. Survey respondents were asked to assess the state of education in the country, rate two reforms (UNT and 12-year schooling) on a 5-point Likert scale, and provide open-ended comments regarding the two reforms in questions. Two-thirds of the survey respondents were teachers and the remaining respondents were school administrators.

3. Semi-structured interviews that lasted about 40 minutes and focused on interviewees' evaluation of current educational policy frameworks; the nature of teaching and learning in schools; values deemed important in the schooling system (e.g., equity, efficiency, quality, choice, local versus central governance, etc.); and the role of different actors (teachers, students, administrators, the government, etc.) in the educational process.

4. For instance, the average number of students was 28 in rural primary schools and 90 in basic (up to grade 9) schools in 2003. Small-sized schools comprise $50 \%$ of the total number of schools in Kazakhstan.

5. The rationalization policy resulted in high attrition rates among school-aged children, considerable hardship to students who had to walk large distance to integrated schools, and deteriorating quality of education in receiving schools which were forced to operate in several shifts 
6. While funds have been earmarked for pre-school education after 2000, progress has been slow

7. Overall, health issues affect the country's school-aged children: according to a UNICEF study, between 1991-2001, there has been a 7\% increase in the number of sick children and the national mortality rate increased from 8.2 to 10.2 per 1000 . Prevalence of iron deficiency among children under five exceeds 50 percent of the total number (UNICEF, 2005). One in ten children under 14 had tobacco, alcohol, or drug addiction (NHDR, 2004). 8. The inclusion of history as a multiple-choice exam has raised some concerns. In 2005, this subject garnered the highest proportion of appeals (108 out of 371), with a common complaint that not all test questions were in the school curriculum

9. Total allocations for education did not exceed 3.4\% of GDP (NHDR, 2004), against the recommended 6\% of the GDP (the Education for All).

\section{References:}

Abzhanov, (2005, June 24) Otechestvu predanno sluzhit' [To serve the homeland loyally], Kazakhstanskaya Pravda, p.4.

Anderson, C. (1961) Methodology of comparative education, International Review of Education, VII, 1-23.

Apple, M. (1995). The Politics of a National Curriculum, in P. Cookson, Jr. and Barbara Schneider (Eds.) Transforming Schools (Garland Publishing), 345-370.

ADB (Asian Development Bank) (2002) Project completion report on the Educational Rehabilitation and Management Improvement Project in Kazakhstan.

Asanova, J. (2007) Nation building and post-Soviet Kazakhstan's literature curriculum, in a Special Issue 'Education and Identity Formation in Eastern Europe and Asia', Compare: A Journal of Comparative Education, 37(3).

Asanova, J. (2006) Emerging regions, persisting rhetoric of educational aid: The impact of the Asian Development Bank on educational policy making in Kazakhstan, International Journal of Educational Development, (26), 555-566.

Bacon, E. (1980) Central Asians under Russian rule, A Study in culture change. Cornell University Press, New York.

Bahry, S. A., Niyozov, S. and Shamatov, D. (forthcoming). Bilingual Education in Central Asia.In J.Cummins (Ed.), Bilingual Education, Vol. 5 of N. Hornberger (Ed .) Encyclopedia of Lanquage and Education. Berlin: Springer-Verlag.

Blum, D. (2003). Globalization, National Identity, and Agency: Constructing Youth Culture in the Transcaspian Region, paper presented at the Central Eurasian Studies Society Conference, Cambridge, MA.

Carnoy, M and D. Rhoten. (2002). What Does Globalization Mean for Educational Change? A Comparative Approach, Comparative Education Review, 46(1), 1-9.

Chapman, D., J. Weidman, M. Cohen, and M. Mercer (2005). The search for quality: A five country study of national strategies to improve educational quality in Central Asia, International Journal of Educational Development, 25(5), 514-530. 
Culpeper, R. (1997). The Multilateral Development Banks, Volume 2. Boulder, CO and London: Lynne Rienner.

Dale, R., \& S. Robertson. (2002). The varying effects of regional organizations as subjects of globalization of education, Comparative Education Review, 46(1), 10-36.

Dave, B. (2003) Freedom House report - nations in transit: Kazakhstan (Washington, DC, Freedom House).

Dei, Sefa G. (2005). The challenge of inclusive schooling in Africa: a Ghanaian case study, Comparative Education, 41(3), 267-289.

DeYoung, A. \& B. Suzhikova. (1997). Issues in Post-Soviet secondary school reform: The case of Kazakhstan. International Journal of Educational Reform, 6(4), 441-454.

DeYoung, A.J. and B. Nadirbekyzy (1996). Redefining schooling and community in postSoviet Kazakstan, Politics of Education Association Yearbook, 71-78.

Drummond, T. (2006) A Review of Selection Examination Reforms in Three Central Asian Republics: Prospects for Long-Term Sustainability, a paper presented at the Central Eurasian Studies Society conference, University of Michigan.

Dyusebek,A. (2005), Alemdik biilim kengistigine yqpaldasu zhagdaiynda orta bilim zhuyesin mazmundyq zhane qurylymdyq zhetildiru maselelri [The problems of developing the secondary education content and structure in the globalized system], Otrytaia shkola [Open School], 11(48), 3-5.

Duysebek, A.(2004) Ulttyq biryngai testiley - bilim sapasyn anyqtaudyng ob'ektivti tasili [Unified National Testing is an objective method of determining the quality of education], Bilim-Obrazovanie, 3(17), 16-20.

Edwards, R. et al. (eds.) (1973). Relevant Methods in Comparative Education. Hamburg: Unesco Institute for Education.

Fagerlind, I. \& A. Kanaev, (2000). Redefining citizenship education in the Central Asian countries, Educational Practice and Theory, 22(1), 95-113.

Farrell, J. (2000). Why Is Educational Reform so Difficult? Similar descriptions, different prescriptions, failed explanations, Curriculum Inquiry, 30(1), 83-103.

Gosudarstvennaia programma Funktsionirovania i razvitia iazykov na 2001-2010 gody [State Program for the functioning and development of languages for 2001-2010]. (2006). Osnovnye zakonodatel'nye akty o iazykah v respublike Kazakhstan [Basic legislative acts about languages in the Republic of Kazakhstan], Almaty: Urist, 18-38.

Heyneman, S. (2000) From the party/state to multiethnic democracy: Education and social cohesion in Europe and Central Asia, Educational Evaluation and Policy Analysis, 22(2), 173-91.

Janmaat, J. and E. Vickers (2007). Education and Identity Formation in Eastern Europe and Asia: an editorial. Compare: A Journal of Comparative Education, 37(3).

Johnson, M. (2004) The legacy of Russian and Soviet education and the shaping of ethnic, religious, and national identities in Central Asia. In Stephen P. Heyneman and Alan J. DeYoung (Eds) The Challenges of Education in Central Asia: International Perspectives on Educational Policy, Research, and Practice. Information Age Publishing, 21-36.

Jones, P. (1997) On World Bank education financing. Comparative Education, 33 (1): 117129.

88 Canadian and International Education Vol. 36 no 2 - October 2007 
Kahne, J., \& Westheimer, J. (2003). Teaching democracy: what schools need to do, Phi Delta Kappan, 85(1), 34-40, 57-60, 63-66.

Kissane, C. (2005). History education in transit: where to for Kazakhstan? Comparative Education, 41(1), 45-69.

Kontseptsia etnokul'turnogo obrazovania v Respublike Kazakhstan [The Concept of Ethnocultural education in the Republic of Kazakhstan, approved by the President on June 15, 1996]. (2005). Uchitel' i zakon [The Teacher and Law], 2(11).

Kusainov, A. (2005, January 14). Bugingi maksat - ulttyq tarbie [Today's objective is ethnic upbringing], Qazaq Adebieti (Almaty).

Lauglo, J. (1996). Banking on education and the uses of research: a critique of World Bank Priorities and Strategies for Education. International Journal of Educational Development, 16(3), 221-33.

Lisovskaya, E. \& Karpov, V. (1999). New ideologies in post-communist Russian textbooks, Comparative Education Review, 43(4), 522-43.

McNeely, C. (1995) Prescribing national education policies: The role of international organizations, Comparative Education Review, 39(4), 483-507.

Minister of Education. (2005, February 18). Tsel' strategii obrazovania - vostrebovannost' spetsialista $\mathrm{v}$ liuboi strane [The goal of educational strategy is recognition of a skilled worker in any country], Uchitel' Kazahstana [Kazakhstan's Teacher].

Mukanova, S. (2005) Modernizatsia sistemy srednego obschego obrazovania Respubliki Kazakhstan $\mathrm{v}$ kontekste mezhdunarodnyh tendentsii razvitia srednego obrazovania. otkrytaia shkola [Modernization of the ], 12(49) 8-10.

Mundy, K. (2007). Educational Multilateralism: Origins and Indications for Global Governance. In Martens, Kerstin; Rusconi, Alessandra; Leuze, Kathrin (Eds) New Arenas of Education Governance - The Impact of International Organisations and Markets on Educational Policymaking. Houndmills, Basingstoke: Palgrave.

Mundy, K. (1998). Educational Multilateralism and World (Dis) Order, Comparative Education Review, 42(4): 448-479.

NHDR (2004). National Human Development Report Kazakhstan 2004: Education for All: the Key Goal for a New Millennium (UNDP).

Rao and Rubina, (2005) business education in the former soviet union republic of Kazkahstan: a former dean's perspective. In MdIntyre, R.J. and Ilan Alon (eds.) Business and Management education in transitioning and developing countries. A handbook. Armonk, N.Y.: M.E. Sharpe (Chapter 9, p 135-45).

Saha, L. (2000). Education and active citizenship: Prospects and issues, Educational Practice and Theory, 22(1), 9-20.

Samoff, J. (1996). “Which Priorities and Strategies for. Education?” International Journal of Educational Development, 16(1), 249-271

Silova, I. (2005) Traveling policies: hijacked in Central Asia, European Educational Research Journal, 4(1), 50-59.

Stromquist, N. (2006). Gender, education and the possibility of transformative knowledge, Compare, 36(2), 145-161 
Suleimenova, E.D. \& Smagulova, Zh. S. (2005). Iazykovaia situatsiia i iazykovoe planirovanie v Kazakhstane. (Almaty, Kazakhstan: Qazaq universiteti).

Tse, K-C. T. (2003). Civics and Citizenship, In John Keeves and Ryo Watanabe (Eds.), International Handbook of Educational Research in the Asia-Pacific Region (Dordrecht, Netherland: Kluwer Publishers), 555-568.

USAID (United States Agency for International Development) (2004) Kazakhstan Overview, retrieved from http://www.usaid.gov/pubs/cbj2003/ee/kz/ on May 22, 2005.

Valyayeva, G. (2006) Standardized Testing for University Admissions in

Kazakhstan: A Step in the Right Direction? A paper presented at the Central Eurasian Studies Society conference, University of Michigan.

Zajda, J. (2003). Why Education Reforms Fail? European Education, 35(1), 58-88.

Zharkynbaeva, R. (2005). Politika Kazakhstana v sfere obrazovania: real'nost I perspectivy [Kazakhstan's education policy: reality and prospect], Saiasat-Politika [Politics], 45-50.

Jazira Asanova is currently teaching at OISE/University of Toronto . She holds a doctorate in Education Policy and Leadership from Hofstra University and has previously taught at Wilfrid Laurier University . Jazira??s research interests include international development agencies, globalization and education, and educational reform in transition countries. She has published articles on issues of schooling, inclusion, and educational reform. 